\title{
The effect of dietary nitrate on nitrate and nitrite excretion in man
}

\author{
BY T. H. J. FLORIN ${ }^{1}$, G. NEALE ${ }^{2}$ AND J. H. CUMMING $S^{1}$ \\ ${ }^{1}$ MRC Dunn Clinical Nutrition Centre, 100 Tennis Court Road, Cambridge CB2 1QL \\ ${ }^{2}$ Addenbrooke's Hospital, Hills Road, Cambridge CB2 $2 Q Q$
}

(Received 5 September 1989 - Accepted II May 1990)

\begin{abstract}
Dietary nitrate and nitrite may affect colonic pathophysiology. These anions influence fermentation, and nitrite has been shown to augment sodium absorption by the colon and participate in the formation of $\mathrm{N}$-nitroso compounds. There is, however, no general agreement as to how much dietary nitrate and nitrite reaches the colon. To help resolve this question, balance studies were performed on six healthy ileostomy subjects who were given diets that varied in nitrate content from 0.83 to $5.20 \mathrm{mmol} / \mathrm{d}$. Nitrate and nitrite excretion in ileal effluent and urine were measured by anion-exchange chromatography with conductivity detection. There was no significant nitrite in the diets, urine or ileal effluent. Dietary nitrate was largely excreted in urine (1.31-4.25 mmol/d). The urinary excretion findings indicated net synthesis of nitrate at low dietary intakes and net catabolism of nitrate at high intakes. Nitrate losses in ileal effluent were very low $(0.03-0.05 \mathrm{mmol} / \mathrm{d}, 0.03-0.06 \mathrm{mmol} / \mathrm{kg})$ and unrelated to intake for all the diets. It is concluded that dietary nitrate and nitrite do not enter the colon from the small intestine in amounts that would affect fermentation and mucosal metabolism in man. The possibility of significant amounts of nitrate reaching the colon via blood in normal subjects has not been excluded.
\end{abstract}

Nitrate: Nitrite: Human colon: Ileostomy

Nitrate and nitrite may be important in gastrointestinal pathophysiology for a number of reasons. Nitrite can react with secondary amines, amides and urea to form $N$-nitroso compounds (Hawksworth \& Hill, 1971). These compounds, which are potential carcinogens and mutagens (Hartman, 1982), can be generated in the stomach (Ruddell et al. 1978), where they have been implicated with human gastric cancer (Hill et al. 1973; Zaldivar \& Robinson, 1973; Cuello et al. 1976), although this is not universally accepted (Forman et al. 1985). Nitrosamines have also been detected in human faeces (Wang et al. 1978; Suzuki \& Mitsuoka, 1981). The levels were low, and artefactual interference has not been excluded (Lee et al. 1981; Suzuki \& Mitsuoka, 1985).

Bacterial metabolism of nitrate is reductive, the first product being nitrite. In some bacteria this reduction is assimilatory, with the incorporation of nitrate-nitrogen into microbial amino acids. Other anaerobic bacteria dissimilate nitrate by coupling its reduction to phosphorylation (Ota, 1982). The large intestine is the site of intense anaerobic bacterial activity, and so these anions may influence fermentation in the colon (Allison \& Macfarlane, 1988). Furthermore, nitrite affects colonic mucosal metabolism in the rat, as lumen nitrite augments sodium absorption, possibly by stimulating $\beta$-oxidation in the colonocyte (Roediger et al. 1986).

The mean daily dietary intake of nitrate in England has been estimated to be $1.74 \mathrm{mmol}$ (calculated from Knight et al. 1987). There is, however, wide inter-individual variation. One reason is varied consumption of water, in which nitrate concentration also varies widely (Knight et al. 1987). Another reason is differences in vegetable consumption. Some vegetables, lettuce, spinach and celery for example, may contribute over $90 \%$ of ingested 
nitrate in food (Walker, 1975; Knight et al. 1987). Therefore, significant differences in ingested nitrate are likely to occur between some vegetarians and omnivores.

The mean daily intake of nitrite has been estimated to be $0.03 \mathrm{mmol}$ (Knight et al. 1987). It is derived mostly from nitrite-cured meats. Although nitrite concentrations in food are much lower, they may be increased by microbial reduction of nitrate during adverse storage conditions (Walker, 1975).

These anions are absorbed from the upper gastrointestinal tract (Bartholomew \& Hill, 1984) and thus may not reach the colon in amounts that would influence colonic physiology. On the other hand, there is excretion of nitrate from blood into saliva (Bartholomew \& Hill, 1984) and excretion may occur from the exocrine pancreas and elsewhere in the intestine (Witter et al. 1979). Significant amounts of nitrate reached the colon of rats given pharmacological doses of nitrate in their drinking water (Witter \& Balish, 1979) and Allison et al. (1988) showed that such amounts could inhibit methanogenesis in rat faeces.

The first published measurements of nitrate and nitrite in human ileostomy fluid implied that large amounts could reach the colon from the small intestine. Tannenbaum et al. (1978) reported concentrations of less than $2 \mu \mathrm{M}$ for nitrate but a mean of $930 \mu \mathrm{M}$ for nitrite. More recently other investigators have reported nitrate levels at $20.5 \mu \mathrm{M}$ or less, and nitrite levels at $40 \mu \mathrm{M}$ or less (Saul et al. 1981; Bartholomew \& Hill, 1984; Radcliffe et al. 1985, 1989). It has been suggested that some variation in ileal concentrations is due to differences in the amount of these anions ingested (Radcliffe et al. 1985, 1989). However, methodological artefacts might also explain some of the variability because there is no standard and accepted method for measuring these anions in biological samples (Ministry of Agriculture, Fisheries and Food, 1987), and microbial action will alter both nitrate and nitrite, especially in unrefrigerated samples (Walker, 1975; Saul et al. 1981).

The dietary contribution to the colonic pool of nitrate and nitrite is, therefore, uncertain. Because of its potential importance to colonic physiology, we present findings on ileal effluent and urine collected from ileostomy subjects, fed on diets with a range of nitrate contents $(0.83-5 \cdot 2 \mathrm{mmol} / \mathrm{d})$.

The high-performance liquid chromatography method used to measure nitrate and nitrite in the present study uses conductivity detection to measure the anions directly. Different methods have particular strengths and weaknesses. The present method requires large dilutions to separate anion peaks. On the other hand, the Griess method used in the studies cited in our discussion measures nitrite colorimetrically. This is subject to interference in biological samples, and requires nitrate to be reduced to nitrite for its measurement.

\section{METHODS}

\section{Subjects}

Six fit ileostomy subjects (three male, three female), mean age 60 years (range 48-74), volunteered for the study. Apart from one on regular oral diabetic therapy they were not taking any medication. They were of normal weight, mean $63 \mathrm{~kg}$ (range 57-76). Five of the subjects had had colectomies for ulcerative colitis and one for metachronous bowel cancer, all at least 2 years before the study. None had more than $100 \mathrm{~mm}$ of terminal ileum resected. During the study all lived in the metabolic ward of the Dunn Clinical Nutrition Unit.

\section{Diets}

Five diets were constructed from normal foods bought in bulk, stored and prepared in a metabolic kitchen (Table 1). They were designed to have energy, protein, fat and carbohydrate contents typical of a British diet (Bingham et al. 1981) (Table 2). Diets were 
Table 1. Composition of diets $(\mathrm{g} / \mathrm{d})$

\begin{tabular}{|c|c|c|c|c|c|c|}
\hline & $\begin{array}{l}\text { Diet }^{*} \ldots \\
\text { No. of subjects } \\
\text { completing diet... }\end{array}$ & 5 & 2 & 3 & 5 & 3 \\
\hline & Bread & 287 & 300 & 200 & 0 & 200 \\
\hline & Crumpet & 0 & 0 & 83 & 0 & 83 \\
\hline & Butter & 50 & 50 & 50 & 50 & 50 \\
\hline & Oats & 0 & 0 & 0 & 50 & 0 \\
\hline & Grapefruit & 100 & 0 & 0 & 100 & 0 \\
\hline & Ginger jam & 0 & 50 & 0 & 0 & 0 \\
\hline & Cheese & 0 & 0 & 50 & 0 & 50 \\
\hline & Milk (ml) & 150 & 40 & 60 & 150 & 80 \\
\hline & Minced beef $\dagger$ & 100 & 0 & 0 & 100 & 0 \\
\hline & English sausage $\dagger$ & 0 & 160 & 160 & 0 & 0 \\
\hline & Ham & 0 & 0 & 0 & 0 & 113 \\
\hline & Onion & 50 & 0 & 0 & 50 & 0 \\
\hline & Frozen peas & 0 & 0 & 0 & 166 & 0 \\
\hline & Macaroni & 0 & 0 & 0 & 100 & 0 \\
\hline & Potatof & 0 & 0 & 0 & 265 & 0 \\
\hline & White rice $\S$ & 75 & 0 & 0 & 0 & 0 \\
\hline & Packet potato§ & 0 & 30 & 30 & 0 & 30 \\
\hline & Cabbaget & 100 & 150 & 150 & 0 & 0 \\
\hline & Lettuce & 0 & 0 & 0 & 166 & 100 \\
\hline & Brussel sprouts & 0 & 100 & 100 & 0 & 0 \\
\hline & Swede & 0 & 0 & 0 & 0 & 100 \\
\hline & Turnip & 0 & 0 & 0 & 0 & 60 \\
\hline & Beetroot & 0 & 0 & 0 & 0 & 100 \\
\hline & Apple & 0 & 0 & 0 & 120 & 0 \\
\hline & Banana & 80 & 0 & 0 & 0 & 0 \\
\hline & Sultanas & 0 & 100 & 100 & 0 & 100 \\
\hline & Biscuits & 50 & 50 & 50 & 50 & 50 \\
\hline & Tea (cups) & 3 & 2 & 3 & 0 & 4 \\
\hline & Beer $(\mathrm{ml})$ & 0 & 660 & 330 & 0 & 0 \\
\hline & Grape juice (ml) & 0 & 1200 & 600 & 0 & 0 \\
\hline
\end{tabular}

* Unlimited deionized water on all diets.

$\dagger$ Fried in butter ration or own fat.

$\$$ Microwaved.

$\S$ Made with local water.

Table 2. Composition of the diets (values based on food tables, Paul \& Southgate, 1985)

\begin{tabular}{lrrrrr}
\hline & 1 & 2 & 3 & 4 & 5 \\
\hline Diet* $\ldots$ & $8 \cdot 3$ & $11 \cdot 5$ & $11 \cdot 4$ & $8 \cdot 3$ & $9 \cdot 2$ \\
Energy (MJ/d) & 60 & 62 & 70 & 64 & 69 \\
Protein (g/d) & 88 & 87 & 104 & 88 & 103 \\
Fat (g/d) & 241 & 435 & 350 & 238 & 259 \\
Carbohydrate (g/d) & \\
\hline
\end{tabular}

* For details of ingredients, see Table 1.

given in random order, each for $48 \mathrm{~h}$. Three subjects completed two diets, and one subject each completed three, four and five diets. They were encouraged to eat slowly and frequently in small amounts to prevent blockages, as the fibre content of the diets was generally high. Apart from one experiment which was abandoned because of an ileostomy blockage, the subjects ate all the food. They did not feel hungry and did not gain or lose weight during the two study periods. 


\section{Samples}

Ileal effluent and urine were collected during the second $24 \mathrm{~h}$ of each dietary period. Ileostomy bags were emptied at 07.00 hours and every $2 \mathrm{~h}$ thereafter until 23.00 hours, and their contents were frozen at $-20^{\circ}$. The last meal of the day was completed by 20.00 hours so that there were two collections of ileal contents before going to bed. Urine was refrigerated, measured volumetrically and portions were stored at $-20^{\circ}$. Ileal effluent and homogenized duplicate diets were weighed wet, stored at $-20^{\circ}$, and reweighed after freezedrying.

\section{Anion measurement}

Nitrate and nitrite were measured by anion-exchange chromatography (AS4 guard and column, Dionex) using bicarbonate buffer eluant (sodium carbonate $2.25 \mathrm{mM}$, sodium bicarbonate $2.8 \mathrm{~mm}$ ) at a flow-rate of $2 \mathrm{ml} / \mathrm{min}$, cationic suppression (AMMS supressor with sulphuric acid $25 \mathrm{~mm}$, flow $3 \mathrm{ml} / \mathrm{min}$ ) to improve signal noise ratio, and conductivity detection. Analysis was performed on duplicate $0.5 \mathrm{ml}$ samples of supernatant fraction derived from $100 \mathrm{mg}$ sample portions in the following way. Samples of urine, food and ileal effluent were diluted to $10 \mathrm{ml}$ in deionized water and centrifuged to remove particulate material. A portion of supernatant fraction was mixed 1:1 (v/v) with propan-2-ol, centrifuged to remove precipitated protein and the supernatant fraction then diluted in buffer to a final dilution of about $1: 1000(\mathrm{v} / \mathrm{v})$. The sample was then passed through a SepPak (Millipore) cartridge filter to remove organic material before injecting onto the column. The chromatogram peaks were integrated with a Spectraphysics integrator calibrated against an external mixed anion standard, having first subtracted background noise measured in a deionized water blank prepared in the same manner as the samples. The nitrite peak occurred at $3.3 \mathrm{~min}$ and the nitrate peak at $6.4 \mathrm{~min}$ (Fig. 1). As the nitrate peak was not always easy to distinguish from neighbouring separate peaks in ileal effluent and some food samples (but not urine), duplicate effluent and some food samples were spiked with nitrate to identify the peak with certainty.

\section{Method validation}

Anion conductivity was linear over the range of measurement. The background noise in the supernatant fraction due to nitrite was less than $0-1 \mu \mathrm{M}$; the average nitrate background was $0 \cdot 2 \mu \mathrm{M}$. The minimum level of detection for any of the anions in the $1: 1000(\mathrm{v} / \mathrm{v})$ supernatant fractions was less than $0.05 \mu \mathrm{M}$, which corresponds to $0.05 \mathrm{~mm}$ for the undiluted sample. From the wet:dry weight ratios and the maximum $24 \mathrm{~h}$ weights or volumes of ileal effluent $(1 \mathrm{~kg})$, urine (3 litres) and diet $(0.800 \mathrm{~kg})$, the maximum amounts of any anion going undetected by the method are calculated as 5,150 and $40 \mu \mathrm{mol} / \mathrm{d}$ respectively. The mean recoveries of nitrite and nitrate added to effluent sample portions at final dilution concentrations of $0.20 \mu \mathrm{M}, 0.50 \mu \mathrm{M}$ and $1.00 \mu \mathrm{M}$ ranged from 85 to $120 \%$.

Potential nitrate losses from microbiological degradation in the ileostomy bag and urine stored at $4^{\circ}$ were assessed in two subjects. Bag contents were diluted $1: 1(\mathrm{v} / \mathrm{v})$ with a nitrate solution whose final concentration after mixing was $1 \mathrm{~mm}$. The slurries were left to stand in the bags at $25^{\circ}$. Samples were taken at $0 \mathrm{~h}$ and at time-intervals to correlate with the midpoints of the day collections ( $1 \mathrm{~h})$ and night collection $(4 \mathrm{~h})$. Samples were either snapfrozen as performed for the ileal collections, or premixed $1: 1(\mathrm{v} / \mathrm{v})$ with $0.4 \mathrm{M}$-sodium hydroxide and then frozen. Nitrate recoveries in the samples were $90 \%(0 \mathrm{~h}), 74 \%(1 \mathrm{~h})$ and $11 \%(4 \mathrm{~h})$. Addition of alkali to prevent chemical and microbiological degradation did not affect nitrate recoveries, although nitrite did accumulate in some alkali-treated samples. Using this information, potential losses of nitrate in the ileal bag were calculated to be approximately $47 \%$ over $24 \mathrm{~h}$. Sample portions of refrigerated urine were snap-frozen at $0 \mathrm{~h}$ and at intervals up to $24 \mathrm{~h}$. Nitrate recoveries in the samples were $100 \%(0 \mathrm{~h}), 99 \%(4 \mathrm{~h})$, 

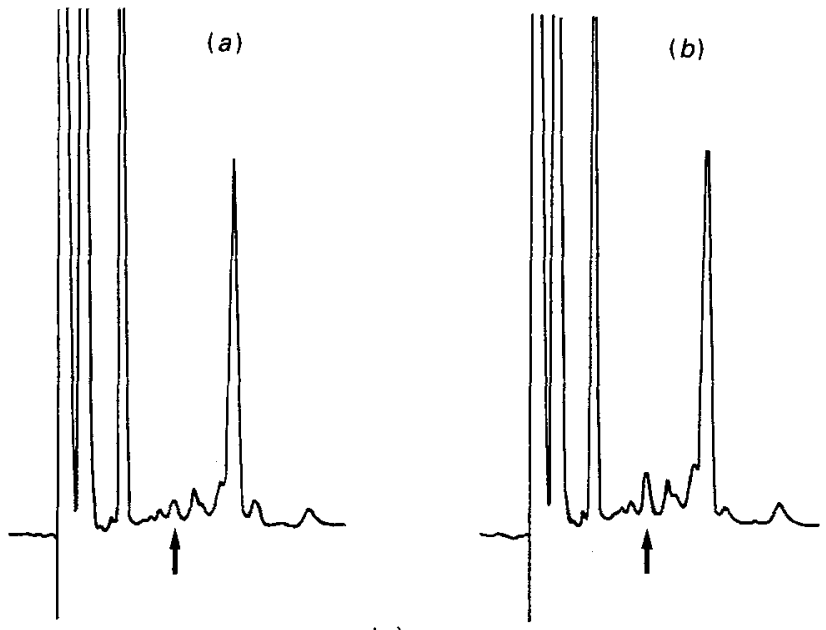

(c)

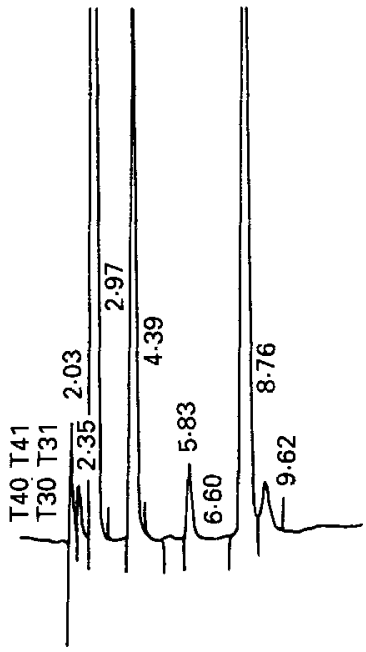

Fig. 1. Chromatograms. (a) Ileal effluent (1:1000, v/v dilution), (b) ileal effluent, same collection, spiked with $0.5 \mathrm{~mm}$-nitrate $(1: 1000, \mathrm{v} / \mathrm{v}),(c)$ urine $(1: 2000, \mathrm{v} / \mathrm{v})$. Conductivity range $1 \mu \mathrm{S}$. Peak markers and peak times have been removed from chromatograms $(a)$ and $(b)$ to improve clarity. Identified peaks are chloride $(2 \cdot 97)$, nitrite not present $(3 \cdot 30)$, phosphate $(4 \cdot 39)$, nitrate $(6 \cdot 60)$, succinate $(7 \cdot 25)$, malate $(7 \cdot 67)$, sulphate $(8 \cdot 76)$, tartrate $(9 \cdot 62)$ and oxalate $(11 \cdot 70)$. The nitrate concentration in the ileal effluent, after subtraction of background and conversion from dry to wet weight was $0.03 \mathrm{mmol} / \mathrm{kg}$ wet weight. Arrows indicate the position of the nitrate peak in chromatograms $(a)$ and $(b)$.

$97 \%(8 \mathrm{~h}), 96 \%(12 \mathrm{~h})$ and $93 \%(24 \mathrm{~h})$. Nitrite was not detected. From this information, it was calculated that potential nitrate losses in $24 \mathrm{~h}$ urine collections were less than $5 \%$. In the final analysis these losses in ileal and urine collections were not important sources of error (see later).

All chemicals were of Aristar grade from BDH or Sigma; water was deionized (greater than 20 MOhms resistivity) and filtered through a $0.2 \mu \mathrm{m}$ filter (Elga).

The study was approved by the Ethics Committee of the Dunn Nutrition Unit.

\section{RESULTS}

Nitrate and nitrite were measured in the constituent foods before constructing the diets. Nitrate concentrations were less than $1 \mathrm{mmol} / \mathrm{kg}$ except for beetroot $(30 \mathrm{mmol} / \mathrm{kg})$, cabbage (range $1-4 \mathrm{mmol} / \mathrm{kg}$ ), lettuce $(30-65 \mathrm{mmol} / \mathrm{kg})$, swede and turnip 
Table 3. Nitrate in diets, ileal effuent and urines of six healthy ileostomists

(Mean values with their standard errors)

\begin{tabular}{|c|c|c|c|c|c|}
\hline \multirow[b]{3}{*}{$\operatorname{Diet}^{*}(\mathrm{mmol} / \mathrm{d}) \ldots$} & \multicolumn{5}{|c|}{ Diet* } \\
\hline & 1 & 2 & 3 & 4 & 5 \\
\hline & 0.83 & 1.07 & $2 \cdot 07$ & 2.53 & $5 \cdot 20$ \\
\hline \multicolumn{6}{|c|}{ Ileal effluent $(\mathrm{mmol} / \mathrm{d})$} \\
\hline Mean & 0.03 & 0.05 & 0.04 & 0.03 & $0-04$ \\
\hline SE & 0.005 & $0 \cdot 006$ & 0.012 & 0.007 & 0.006 \\
\hline \multicolumn{6}{|c|}{ Ileal effluent $(\mathrm{mmol} / \mathrm{kg})$} \\
\hline Mean & 0.06 & 0.04 & 0.03 & $0-05$ & 0.03 \\
\hline SE & $0 \cdot 010$ & 0.016 & $0-009$ & 0.012 & $0-006$ \\
\hline \multicolumn{6}{|l|}{ Urine $(\mathrm{mmol} / \mathrm{d})$} \\
\hline Mean & $1 \cdot 31$ & $1 \cdot 32$ & 1.67 & $2 \cdot 50$ & $4 \cdot 25$ \\
\hline $\mathrm{SE}$ & 0.071 & $0 \cdot 116$ & $0 \cdot 260$ & 0.396 & $0 \cdot 457$ \\
\hline \multicolumn{6}{|l|}{ Balance $f(\mathrm{mmol} / \mathrm{d})$} \\
\hline Mean & -0.51 & $-0 \cdot 31$ & $0 \cdot 36$ & 0.00 & 0.91 \\
\hline SED & $0 \cdot 104$ & 0.199 & $0 \cdot 318$ & 0.616 & $0 \cdot 778$ \\
\hline
\end{tabular}

SED, standard error difference of means

* For details of diets, see Tables 1 and 2 .

$\uparrow$ Balance $=($ diet - ileal effluent - urine $)$.

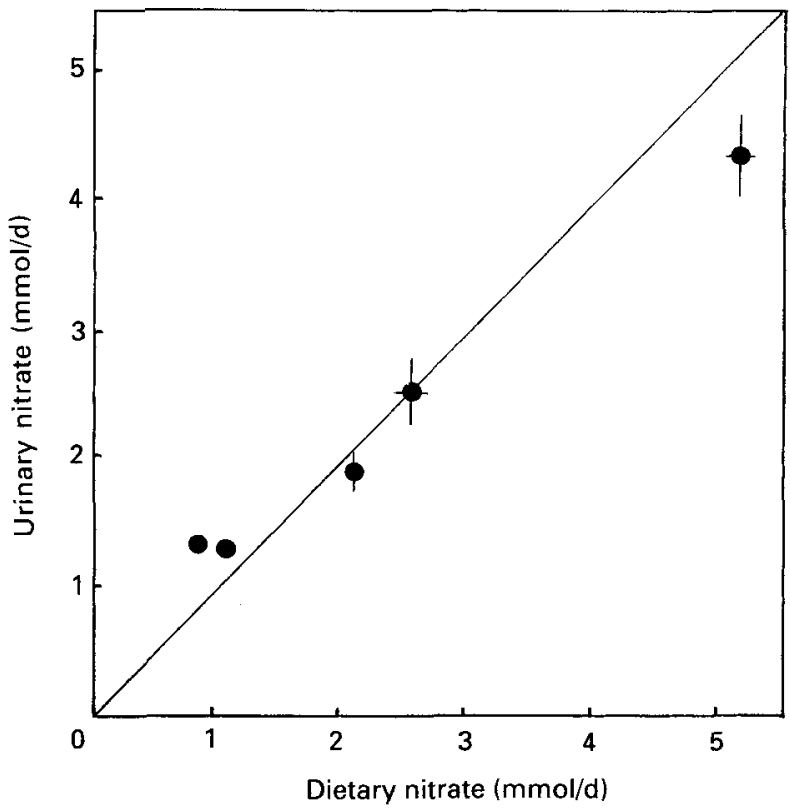

Fig. 2. Urinary excretion of nitrate $v$. dietary intake. Values are means with their standard errors, represented by vertical bars. The straight line represents the theoretical line on which values would fall if all ingested nitrate were excreted in urine and none was synthesized or catabolized.

$(4-30 \mathrm{mmol} / \mathrm{kg})$. The concentration of nitrate in Cambridge water was $0.6 \mathrm{~mm}$. The only food that contained significant nitrite was the ham with $2 \cdot 2 \mathrm{mmol} / \mathrm{kg}$.

No nitrite was detected in any of the unspiked samples of whole diet, urine or ileal fluid. The balance findings for nitrate are summarized in Table 3 . The $24 \mathrm{~h}$ dietary nitrate 
varied between mean 0.83 (SE 0.03 ) and 5.2 (SE 0.3 ) mmol. Mean nitrate concentration in ileal effluents was 0.042 (SE 0.006) $\mathrm{mmol} / \mathrm{kg}$ and $24 \mathrm{~h}$ ileal excretion was 0.038 (SE 0.004) $\mathrm{mmol}$. There was no correlation between the intake of nitrate and its excretion or concentration in ileal effluent. Nitrate excretion from the ileum remained very low throughout the study. The $24 \mathrm{~h}$ excretion of nitrate in urine ranged from 1.31 (SE 0.08 ) mmol to 4.25 (SE 0.45 ) $\mathrm{mmol}$ and correlated with dietary intake (regression coefficient $0.98, t 10 \cdot 0$, $P<0 \cdot 001$ ), consistent with ingested nitrate being largely excreted in the urine of the subjects (Fig. 2). Nitrate excretion in urine was greater than intake for the two diets with lowest nitrate. This negative balance was statistically significant $(P<0.01)$ for diet 1 with a net nitrate excretion of 0.51 (SE 0.12$) \mathrm{mmol} / \mathrm{d}$ which was $39 \%$ more than intake. There was a trend, which was not statistically significant, for an apparent positive nitrate balance at higher intakes, with excretion being $17 \%$ less than intake for diet 3 and $18 \%$ less for diet 5 .

\section{DISCUSSION}

These are the first reported balance studies in man to relate dietary intake of nitrate to its output in urine and ileal effluent. The output was measured over a sixfold range of intake. Although diets could be designed to contain more nitrate, by including more vegetables rich in nitrate, the highest intake in the present study was three times the national average as calculated by Doll's group (Knight et al. 1987) and more than 1.5 times the intake for an extremely high consumer of nitrate as calculated by the Ministry of Agriculture, Fisheries and Food (1987).

Nitrate concentrations in the nitrate-rich foods used in the present study (beetroot, cabbage, lettuce, swede and turnip) are similar to those reported elsewhere (Knight et al. 1987). The nitrate content of the highest nitrate diet (diet 5) predicted from the maximum measured nitrate of the constituent foods was greater than $14 \mathrm{mmol}$. The difference between this value and the measured nitrate of the highest nitrate diet $(5.2 \mathrm{mmol})$ reflects the enormous range of nitrate concentrations in individual foods (Walker, 1975; Knight et al. 1987).

There was no significant nitrite $(<40 \mu \mathrm{mol})$ in the diets. This is not surprising as the predicted amount in any of the diets was less than $35 \mu \mathrm{mol}$ and the presence of this anion in larger amounts would have indicated bacterial degradation due to poor storage (Walker, 1975).

The nitrate content of the ileal collections $(38 \mu \mathrm{mol} / \mathrm{d}, 42 \mu \mathrm{mol} / \mathrm{kg}$ ) was uniformly low and unrelated to dietary content. Even when account is taken of nitrate losses in the ileostomy bags (about $50 \%$; see validation section in methods), the ileal effluent nitrate content is still very low. No nitrite $(<5 \mu \mathrm{M})$ was found. Therefore, nitrate and nitrite do not reach the colon from the small intestine in man in amounts that would influence colonic pathophysiology by mass action, even after the consumption of diets rich in nitrate.

The present ileal effluent concentrations of nitrate and nitrite are different from some of those reported by other investigators. (There is no other available information on daily ileal excretion.) Saul et al. (1981) reported barely detectable levels of nitrate $(<7 \mu \mathrm{mol} / \mathrm{kg})$ but higher nitrite levels $(<15 \mu \mathrm{mol} / \mathrm{kg})$, whereas Tannenbaum et al. (1978) reported mean values of $<2$ and $930 \mu \mathrm{mol} / \mathrm{kg}$ respectively; these values were subsequently withdrawn (Tannenbaum \& Green, 1981). Bartholomew \& Hill (1984) reported mean concentrations of $40 \mu \mathrm{mol} / \mathrm{kg}$ for both nitrate and nitrite. Only Radcliffe et al. $(1985,1989)$ reported, like the present findings, higher nitrate than nitrite concentrations.

The findings in the present study with low ileal concentrations of nitrate and even lower concentrations of nitrite over a sixfold dietary range are more or less in agreement with ileal concentrations found by Radcliffe et al. $(1985,1989)$. However, they concluded that diet did influence the concentrations of nitrate and nitrite entering the colon from the small 
intestine in man. They reported increased concentrations of these anions following a putative nitrate-rich evening meal, which contained spinach, beetroot, lettuce, radishes and celery. However, they did not report total nitrate or nitrite in ileal effluent and did not measure nitrate or nitrite in their control or test meals. Moreover, the control meals were self-selected and all meals were eaten at home. Because of the problem of bacterial degradation of nitrate and nitrite in overnight ileal collections which lasted 14-16 h, they also measured stomal concentrations of these anions. It is therefore pertinent that they reported no statistical difference between the nitrate concentrations in stomal fluid following the two diets. Nitrite concentrations were higher in stomal fluid following the test meal, but the concentrations were very low (less than $5 \mu \mathrm{M}$ ), which is in agreement with our results.

The present findings indicate that ingested nitrate is mainly excreted in urine (Fig. 2). This is consistent with rapid absorption by the upper gastrointestinal tract of this monovalent anion and its excretion by the kidney (Bartholomew \& Hill, 1984).

At low levels of nitrate ingestion, there was a significant negative balance (Table 3 ). This has been noted in other reports where, excess urinary excretion of nitrate was seen in subjects on low dietary nitrate intakes (Mitchell et al. 1916; Green et al. 1981 a; Lee et al. 1986). This has usually been ascribed to endogenous synthesis of nitrate by the reticuloendothelial system. Rodents injected with endotoxins have increased urinary nitrate (Wagner et al. 1983 b). This phenomenon did not occur in mice with a genetic reticuloendothelial defect which makes them hyporesponsive to endotoxin (Stuehr \& Marletta, 1985), and in vitro experiments indicated nitrite and nitrate synthesis from L-arginine by stimulated macrophages (Iyengar et al. 1987). Bartholomew \& Hill (1984) have argued that excess urinary nitrate was due to unmeasured nitrate in the diet, but the present findings on dietary nitrate, argue against this proposition. Finally, the possibility that the excess nitrate is due to nitrification by gastrointestinal bacteria (Tannenbaum et al. 1978), which was always highly improbable given that the bowel lumen has an extremely negative redox potential, has been disproved by studies with germ-free rats (Green et al. 1981 b; Witter et al. 1982).

Urinary nitrate recoveries for the higher nitrate diets in the present ileostomy study $(2 \cdot 07$, 2.50 and $5.2 \mathrm{mmol}$ ) were 83,100 and $82 \%$ of intake respectively (Table 3 ). These results are broadly similar to results from nitrate feeding studies in normal subjects, and there is agreement that nitrite is not found in urine unless there is bacterial infection. Kurzer \& Calloway (1981) recovered $86 \%$ of $5.38 \mathrm{mmol}$ dietary nitrate and Tannenbaum's group (Wagner et al. 1983a) recovered $74 \%$ of an oral dose of ${ }^{15} \mathrm{~N}$-labelled nitrate $(3.7 \mathrm{mmol})$ as either labelled nitrate, nitrite, ammonia or urea in facces and urine.

There are several reasons why recovery of ingested nitrate might be incomplete. Nitrate is lost in urine. From our method validation results, this might be as much as $0.22 \mathrm{mmol}$ for the highest nitrate intake. Furthermore, intestinal bacteria rapidly reduce nitrate and nitrite (Witter \& Balish, 1979; Saul et al. 1981), a result we also noted during method development. Therefore, bacterial degradation of ingested nitrate reaching the intestinal lumen could explain some losses in our subjects. However, Schultz et al. (1985) have emphasized that upper gastrointestinal bacteria are likely to be much less important than colonic bacteria in the degradation of nitrate. This might explain the generally greater nitrate recoveries in our ileostomy subjects.

If bacterial metabolism in the colon is the most important sink for nitrate, then it can be inferred from the results of the present study that nitrate must reach the colon via blood (Schultz et al. 1985). The principal evidence for this comes from labelled nitrate and nitrite experiments in rats and mice. These showed greater recoveries of ${ }^{15} \mathrm{~N}$-labelled products in urine from germ-free than conventional rats (Schultz et al. 1985) and the presence of 
reduction products of ${ }^{13} \mathrm{~N}$-nitrite in the intestine of conventional but not germ-free mice (Thayer et al. 1982). Because nitrate and nitrite were introduced by non-oral routes in these animal experiments, it followed that these substances must have reached the intestine by a vascular route. However, apart from inference from recovery data there is no definitive evidence in man for extensive colonic bacterial degradation of nitrate. Wagner et al. (1983a) found less than $0.2 \%$ of labelled nitrate-derived $\mathrm{N}$ in faeces. These authors argued that nitrate was being metabolized, presumably by gut bacteria, to gaseous products excreted in breath or flatus. However, in vitro experiments with human faecal slurries (Allison \& Macfarlane, 1988) and rumen slurries (Jones, 1972; Kaspar \& Tiedje, 1981) have shown that denitrification of nitrate to $\mathrm{N}_{2}$ is functionally insignificant compared with nitrate dissimilation to ammonia. Another possible explanation for the poor recovery in the experiment of Wagner et al. (1983a) would be that the ${ }^{15} \mathrm{~N}$ exchanged in part with a slowturnover body pool of $\mathrm{N}$.

The situation is made possibly more complex by the finding of incomplete recoveries of nitrate in germ-free animals (Schultz et al. 1985). These authors concluded from this that there exists a reductive mammalian metabolism of nitrate, but there is no in vivo evidence for this (Witter \& Balish, 1979). Because the rats in the study of Schultz et al. (1985) were not truly germ-free, some bacterial metabolism would have been possible, as indeed would be the case in the present study where ileostomy subjects have much lower intestinal bacterial loads than normal human subjects. Another possible reason for incomplete recovery of nitrate is unmeasured losses in sweat (Batholomew \& Hill, 1984). These authors estimated that about $10 \%$ of ingested nitrate might be lost this way, although there are no findings available to confirm this suggestion.

An approximate upper limit for the amount of nitrate that could reach the colon from blood can be calculated by adding endogenous nitrate synthesis (about $1 \mathrm{mmol} / \mathrm{d}$ in healthy subjects; Schultz et al. 1985) to the nitrate not recovered in urine for a given intake. Such a hypothetical value is based on the assumptions that there are no other losses through sweat (Bartholomew \& Hill, 1984), oral bacterial metabolism of salivary nitrate (Spiegelhalder et al. 1976), upper gastrointestinal bacterial metabolism or reductive mammalian metabolism of nitrate (Schultz et al. 1985). Because firm information is lacking, experiments are currently being performed in man to assess directly whether significant nitrate reaches the colon via blood.

On the other hand the present findings are consistent with large amounts of nitrate entering the stomach, proximal small intestine and bladder following a nitrate-rich diet. It seems prudent, therefore, to monitor possible effects of dietary nitrate in 'at-risk' groups, especially at a time when vegetables are rightly being promoted as healthy foods and nitrate levels in them and water may be rising.

The authors are most indebted to Dr Sheila Bingham and Eileen Collard for help with the diets, to the nursing staff, and to the ileostomy volunteers, without whose cheerful collaboration the study would not have been possible. T.H.J.F. gratefully acknowledges support from the East Anglia Health Authority, and is a recipient of the Underwood Trust Fellowship from the British Digestive Foundation.

\section{REFERENCES}

Allison, C. \& Macfarlane, G. T. (1988). Effect of nitrate on methane production and fermentation by slurries of human faecal bacteria. Journal of General Microbiology 134, 1397-1405.

Allison, C., Miller, T. L. \& Wolin, M. J. (1988). The effect of inorganic nitrogen compounds on methane production by large intestinal bacteria. Annual Proceedings of the American Society of Microbiology 88, 123.

Bartholomew, B. \& Hill, M. J. (1984). The pharmacology of dietary nitrate and the origin of urinary nitrate. Food and Chemical Toxicology 22, 789-795. 
Bingham, S., McNeil, N. I. \& Cummings, J. H. (1981). The diet of individuals: a study of a randomly chosen cross section of British adults in a Cambridgeshire village. British Journal of Nutrition 45, 23-35.

Cuello, C., Corres, P., Haenszel, W., Gordillo, G., Brown, C. \& Archer, M. (1976). Gastric cancer in Colombia. 1. Cancer risk and suspect environmental agents. Journal of National Cancer Institute 57, 1015-1020.

Forman, D., Al-Dabbagh, S. \& Doll, R. (1985). Nitrates, nitrites alld gastric cancer in Great Britain. Nature 313, 620-625.

Green, L. C, de Luzuriaga, K. R., Wagner, D., Rand, W., Istfin, N., Young, V. R. \& Tannenbaum, S. R. (1981 a). Nitrate biosynthesis in man. Proceedings of the National Academy of Sciences, USA 78, $7764-7768$.

Green, L. C., Tannenbaum, S. R. \& Goldman, P. (1981 b). Nitrate synthesis in the germ-free and conventional rat. Science 212, 56-58.

Hartman, P. E. (1982). Nitrates and nitrites: ingestion, pharnacodynamics and toxicology. In Chemical Mutagens, vol. 7, pp. 211-294 [F. J. de Serres and A. Hollaender, editors]. New York: Plenum Press.

Hawksworth, G. M. \& Hill, M. J. (1971). Bacteria and the N-nitrosation of secondary amines. British Journal of Cancer 25, 520-527.

Hill, M. J., Hawksworth, G. M. \& Tattersall, G. (1973). Bacteria, nitrosamines and cancer of the stomach. British Journal of Cancer 28, 562-567.

lyengar, R., Stuehr, D. J. \& Marletta, M. A. (1987). Macrophage s/nthesis of nitrite, nitrate and $N$-nitrosamines. Proceedings of the National Academy of Sciences, USA 84, 6369-6373.

Jones, G. A. (1972). Dissimilatory metabolism of nitrate by the rumen microbiota. Canadian Journal of Microbiology 18, I783-1787.

Kaspar, H. F. \& Tiedje, J. M. (1981). Dissimilatory reduction of nitrate and nitrite in the bovine rumen. Applied and Environmental Microbiology 41, 705-709.

Knight, T. M., Forman, D., Al-Dabbagh, S. A. \& Doll, R. (1987. Estimation of dietary intake of nitrate and nitrite in Great Britain. Food Chemistry and Toxicology 25, 277-285.

Kurzer, M. S. \& Calloway, D. H. (1981). Nitrate and nitrogen batances in man. American Journal of Clinical Nutrition 34, 1305-1313.

Lee, L., Archer, M. C. \& Bruce, W. R. (1981). Absence of volatile nitrosamines in feces. Cancer Research 41, 3992-3994.

Lee, K., Greger, J. L., Consaul, J. R., Graham, K. L. \& Chinn, B. 1.. (1986). Nitrate, nitrite balance and de novo synthesis of nitrate in humans consuming cured meat. Americar Journal of Clinical Nutrition 44, $188-194$.

Ministry of Agriculture, Fisheries and Food (1987). Nitrate, Nitite and N-nitroso Compounds in Food. Food Surveillance Paper no. 20. London: H.M. Stationery Office.

Mitchell, H. H., Shonle, H. A. \& Grindley, H. S. (1916). The origin of the nitrates in the urine. Journal of Biological Chemistry 24, 461-490.

Ota, A. (1982). Phosphorylation coupled to nitrate respiration. Inte national Journal of Biochemistry 14, $341 \quad 346$.

Paul, A. A. \& Southgate, D. A. T. (1985). McCance \& Widdowson's The Composition of Foods, 4th ed. London: H.M. Stationery Office.

Radcliffe, B. C., Hall, C. \& Roediger, W. E. (1989). Nitrite and nitrate levels in ileostomy effluent : effect of dietary change. British Journal of Nutrition 61, 323-330.

Radeliffe, B. C., Nance, S. H., Deakin, F. J. \& Roediger, W. E. W. (1985). Nitrate and nitrite content of ileostomy effluent after a normal or high nitrate meal. Clinical and Investizrative Medicine 8 , A94.

Roediger, W. E. W., Deakin, E. J., Radcliffe, B. C. \& Nance, S. (1986). Anion control of sodium absorption in the colon. Quarterly Journal of Experimental Physiology 71, 195-204

Ruddell, W. S. J., Bone, E. S., Hill, M. J. \& Walters, V. L. (1978). Pathogenesis of gastric cancer in pernicious anemia. Lancet i, 521-523.

Saul, R. L., Kabir, S. H., Bruce, W. R. \& Archer, M. C. (1981). R sevaluation of nitrate and nitrite levels in the human intestine. Cancer Research 41, 2280-2283.

Schultz, D. S., Deen, W. M., Karel, S. F., Wagner, D. A. \& Tannenbaum, S. F. (1985). Pharmokinetics of nitrate in humans: role of gastrointestinal absorption and metabolism. Carcinogenesis 6, 847-852.

Spiegelhalder, B., Eisenbrand, G. \& Preussman, R. (1976). Influence of dietary nitrate on nitrite content of human saliva: possible relevance to in vivo formation of $N$-nitroso cornpounds. Food and Chemical Toxicology 14 , 545-548.

Stuehr, D. J. \& Marletta, M. A. (1985). Mammalian nitrate biosynthesis: mouse macrophages produce nitrate and nitrite in response to E. coli lipopolysaccharide. Proceedings of the National Academy of Sciences, USA 82 $7738-7742$.

Suzuki, K. \& Mitsuoka, T. (1981). Increase in faecal nitrosamines in Japanese individuals given a Western diet. Nature 294, 453-455.

Suzuki, K. \& Mitsuoka, T. (1985). Reevaluation of volatile nitrosamines in human faeces. Environmental Toxicology and Chemistry 4, 623-627.

Tannenbaum, S. R., Fett, D., Young, V. R., Land, P. D. \& Bruce, W. R. (1978). Nitrite and nitrate are formed by endogenous synthesis in the human intestine. Science 200, 1487-1489.

Tannenbaum, S. R. \& Green, L. (1981). Metabolism of nitrate. Ir Banbury Report 7, Gastrointestinal Cancer. Endogenous Factors, pp. 331-336 [W. R. Bruce, P. Correa, M. L pkin, S. R. Tannenbaum and T. D. Wilkins, editors]. New York: Cold Spring Harbor Laboratory. 
Thayer, J. R., Chasko, J. H., Schwartz, L. A. \& Parks, N. J. (1982). Gut reactions of radioactive nitrite after intratracheal administration in mice. Science 217, 151--153.

Wagner, D. A., Schultz, D. S., Decn, W. M., Young, V. R. \& Tannenbaum, S. R. (1983a). Metabolic fate of an oral dose of ${ }^{15} \mathrm{~N}$-labelled nitrate in humans. Cancer Research 43, $1921-1925$.

Wagner, D. A., Young, V. R. \& Tannenbaum, S. R. (1983 b). Mammalian nitrate biosynthesis: incorporation of ${ }^{15} \mathrm{NH}_{3}$ into nitrate is enhanced by endotoxin treatment. Proceedings of the National Academy of Sciences, USA 80, $4518-4525$.

Walker, R. (1975). Naturally occurring nitrate/nitrite in foods. Journal of the Science of Food and Agriculture 26, $1735-1742$.

Wang, T., Kakizoe, T., Dion, P., Furrer, R., Varghese, A. J. \& Bruce, W. R. (1978). Volatile nitrosamines in normal human faeces. Nature 276, 280281.

Witter, J. P. \& Balish, E. (1979). Distribution and metabolism of ingested $\mathrm{NO}_{3}$ and $\mathrm{NO}_{2}$ in germfrec and conventional-flora rats. Applied and Environmental Microbiology 38, 861-869.

Witter, J. P., Balish, E. \& Gatley, S. J. (1979). Distribution of nitrogen-13 from labelled nitrate and nitrite in germfree and conventional-flora rats. Applied and Environmental Microbiology 38, 870-878.

Witter, J. P., Balish, E. \& Gatley, S. J. (1982). Origin of excess urinary nitrate in the rat. Cancer Research 42. $3654-3658$.

Zaldivar, R. \& Robinson, H. (1973). Epidemiological investigation on stomach cancer mortality in Chileans: association with nitrate fertilizer. Zeitschrift Krebsforschung 80, 289-295. 